\section{Japan builds ivory towers among its windswept hills}

Kansai Science City. Japan's second major science city, after Tsukuba science city north of Tokyo, is beginning to take shape in the Keihanna hills between Kyoto, Nara and Osaka, about 200 miles west of the nation's capital.

Until recently Kansai science city, in which local and central governments and private industry plan to invest $¥ 4-5$ billion (US\$37-47 million) over the next few decades, was nothing more than a university, a couple of colleges and a handful of institutes widely scattered in the Keihanna hills.

This year, however, has seen the opening of a central service complex and four new institutes - three in the past few weeks alone - in a small district intended to be the heart of the new city.

On 10 November, the central research laboratory of the Research Institute of Innovative Technology for the Earth (RITE) began operations in a futuristic building powered in part by solar cells. The organization is being funded generously by both private companies and the Ministry of International Trade and Industry to develop environment-friendly technology.

The RITE laboratory has 35 researchers, and that number will double over the next five to 10 years. The central building has a slanting roof covered in solar cells. On either side extend two long single-storey wings with large bay windows looking out onto a moat-like pond and a huge landscaped garden.

Next door is the International Institute of Advanced Studies (IIAS), the 'brain centre' of the city, which opened last month and is modelled on the Princeton Institute of Advanced Studies in the United States (see Nature 365, 482; 1993).

Five hundred metres away is the towersearch Institute International (ATR), which was the first institute to open in the city in 1989. It is funded with the dividends of government-held shares in Nippon Telegraph and Telephone Corporation. only 500 hectares. home. ant surroundings. ing Advanced Telecommunications Re-

Facing ATR is the Keihanna Plaza, opened last March, which acts as a central service complex. The world's largest sundial graces a square in front of the complex. And last week, Matsushita Electrical Industrial Company opened its research institute in the same district. It will have a total staff of about 300 when it reaches full operation.

When complete, the city will be composed of 12 such districts or 'clusters', separated by wooded hills. Each district is quite small. The Seika-Nishi Kizu district accommodating the Keihanna Plaza and the new institutes is one of the largest, yet still covers

The 12 clusters will be linked by a computer network centred on the Keihanna Plaza. And planners hope eventually to link all the clusters with a grid system of roads.

At present, however, it is quite difficult to travel between and even within districts. This aspect of Kansai is reminiscent of Tsukuba which, after 20 years of development, still lacks a railway station.

The Keihanna Plaza, which has a concert hall, a hotel, a general store, a travel agency, a bank, a post office and a noodle restaurant that is transformed into a bar at night, is an attempt to make researchers feel more at

But there is still the impression of being in the middle of windswept hills far from civilization. And many of the city's current 6,000 researchers have chosen to live in Kyoto, Nara ur Osaka, 10-30 km away.

There are new housing estates adjacent to the research districts. But house prices were driven to astronomical levels of more than $¥ 100$ million yen ( $\$ 1$ million) during the 'bubble economy' at the end of the 1980 s. Prices have since fallen. But they are still beyond the pocket of most researchers.

It is therefore hard to see how the city will be develop into the "organic whole" that its developers have promised. Rather, there is a danger that the lavishly funded institutes will become ivory towers in pleas-

David Swinbanks

\section{China urged to treat young scientists better}

Peking. A nationwide survey of China's leading young scientists has found that the majority are concerned about low pay, difficult working relationships and poor living conditions.

The survey was carried out by the China Association of Science and Technology, which interviewed 291 winners of the "China Young Scientist Award" working in research laboratories and universities.

The numbers were evenly balanced on the question of whether the scientists felt they were attaining their full potential. Over two-thirds of the scientists agreed that their institutions cared about their work. But three quarters said that they had bad experiences of interpersonal relationships, quoting jealousy, in-fighting and professional rivalry.

As a result of the survey, the association has suggested that research institutions introduce a "more benign attitude" towards young scientists.

\section{Russian foundation challenges power of the Academy}

Moscow. Vladimir Fortov, the new director of the Russian Foundation of Basic Research (RFBR) who took over the helm in June, is trying to persuade the Russian government to double the foundation's budget.

Fortov says he is confident that the foundation, set up in April 1992 along the lines of a Western science funding agency, can use funds far more effectively than the Russian Academy of Science. He says that this is primarily because much of the money channelled to the academy is spent on administration; the RFBR limits overheads to 20 per cent of its budget.

Under Fortov's leadership, new regulations were approved last month which considerably reduce the influence of the foundation's council on decisions by its expert panels on the allocation of research funds. Previously the council had been criticized for allocating a high proportion of grants to its own praesidium members.

The structure of the RFBR is also to change. In particular, an executive committee is being set up to carry out some of the functions of the council between its meetings. And a growth in the number of advisers means that each grant proposal is now reviewed by two experts rather than one.

The foundation's work has been developing rapidly since Fortov replaced Andrei Gonchar, the vice president of the Russian Academy of Science, last summer. This followed a power struggle in which Gonchar was told that he could not continue to hold both positions (see Nature 363, 662; 1993).

Despite the general lack of money in Russia, the foundation has been successful in obtaining from the government most of the money it had been promised. This year it expects to receive about 20 billion rubles (US\$18 million).

Nevertheless some problems still exist. For example, most of the foundation's research projects have been planned to last for three years. This means that about 80 per cent of the programmes now being funded will need funding for the next year - and that next year's competition for funds could end up providing support for only 600 out of an expected 15,000 applications.

The foundation has therefore increased the portion of its budget allocated to research grants from 60 to 75 per cent. This should be sufficient to guarantee funding of 2,200 new projects.

If the budget of the RFBR were to be doubled, its financial power would equal that of the academy, which receives between 10 and 11 per cent of the state annual budget for science. The academy is therefore likely to oppose any such action.

Vladimir Pokrovsky 